\title{
Äro samerna illitterata?
}

\author{
Av länsåklagare KLAS LITHNER, Karlskrona
} lande.

Bakom denna något överraskande titel ligger följande förhål-

I International Annals of Criminology $1970 \mathrm{nr} 1 \mathrm{~s} .57-69$ har professorn i sociologi vid University of New Hampshire Stuart Palmer skrivit en artikel med titeln ,Aggression in Fifty-Eight Non-Literate Societies: An Exploratory Analysis“. Författaren behandlar den i och för sig intressanta frågan om hur aggressionen tar sig utlopp i olika samhällstyper och sambandet mellan mord och självmord ${ }^{1}$ ). Detta problem har tidigare behandlats av några författare, som dock i huvudsak koncentrerat sig på västerländska samfund.

Palmer hänvisar dock till två tidigare studier.

Den första av dessa gäller våld mot person i 48 ,non-literate societies“. ${ }^{2}$ ) Hur adjektivet „non-literate“ skall översättas kan diskuteras. Jag har ej funnit det översatt eller definierat i tillgängliga lexikon och uppslagsböcker, men har $\mathrm{i}$ valet mellan alternativen ,,illitterat" och ,analfabet" föredragit det förra i betydelsen ,kan icke läsa eller skriva“. Denna artikel sammanfattas sålunda av författarna:

„I ett urval av 48 illitterata samfund, korrelerades frekvensen av stöld och brott mot personer var för sig med ett antal variabler, som misstänktes vara orsaksfaktorer för utvecklingen av brottslighet. Brist på eller begränsning av tillfälle för den unge pojken att identifiera sig med sin far var förbunden med båda typerna av brott .... en allmän attityd vid vuxen ålder av misstänksamhet och misstroende voro mera avgjort förbundna med brott mot person".

Författarna ha behandlat 48 samfund från olika delar av världen, dock inga europeiska eller nordvästasiatiska. De ha hämtat sitt material från etnografiska studier antingen i litteraturen eller i „The Human Relations Area Files“ (varom mera nedan).

Palmers andra förstudie är en artikel av honom själv ${ }^{3}$ ). Arti-

1) Jämför Lithner, Mord och självmord - en metodologisk studie, NTfK 1962 s. $280-295$, samt där citerad litteratur.

$\left.{ }^{2}\right)$ Se Margaret K. Bacon, Irvin L. Child and Herbert Barry, A CrossCultural Study of Correlates of Crime, Journal of Abnormal Psychology, 1963 , vol. 66 , No. 4 , s. $291-300$.

3) Se Stuart Palmer, Murder and Suicide in Forty Non-Literate Societies, Journal of Criminal Law, Criminology and Police Science, 1965 , vol. 56 , s. $320-324$. 
kelns uppgift är att undersöka teorin om att mord och självmord stå i omvänd relation till varandra i olika samfund. Palmer har här avsett att pröva teorins tillämpning på illitterata samfund och har hämtat sitt material från samma Human Relations Area Files, där material om mord och självmord fanns tillgängligt för 40 samfund. Bland dessa återfinnas i tabell 2 s. 322 samerna bland de samfund, som ligga under medianen både beträffande mord och självmord.

Jag övergår därefter till den längre och viktigare artikeln i International Annals of Criminology. Även här använder han samma „Files“ som källa (s. 59). Metoden har varit den att han låtit tre bedömare var för sig genomgå de beskrivna samfunden och sätta ett poängvärde på emellan 0 (lägst) och 7 (högst) beträffande 18 olika former av aggressivt uppträdande bland vuxna, t. ex. kannibalism, självplågeri, människooffer, barnamord m.fl. Med utgångspunkt härifrån bestämdes ett ,aggressionsindex“ för varje samfund. „Självmordsindex“ bedömdes med utgångspunkt från en jämförelse med ,litterata“ samfund, där 25 självmord om året per 100.000 invånare motsvarade poängen 7 . Det framgår emellertid icke, hur fördelningen av de låga poängen var (s. 60). Resultatet framgår av tabell $1 \mathrm{~s}$. 61. Detta visar att av 54 (i stället för 58 som i artikelns titel) samfund, ha samerna det lägsta aggressionsindexet (med mord uteslutet), nämligen 1,3, medan index för både mord och självmord är 0 . Högsta index för resp. aggression (utom mord), mord och självmord äro resp. $16,2,21$ och 21. Resultatet är alltså glädjande ur skandinavisk synpunkt. Palmers sammanfattande resultat är att mord och självmord i hans undersökningsmaterial stå i positiv relation till varandra (s. 65).

Efter denna kortfattade redogörelsen för Palmers undersökning och hans viktigaste källor övergår jag till hans uppgift att samerna äro illitterata.

Ett kortfattad redogörelse för ,the Human Relations Area Files“ innehåller följande uppgift: ,Lyckligtvis har vi haft tillgång till Human Relations Area Files, Inc, tidigare känd som Yale's Cross-Cultural Survey. Denna dokumentsamling innehåller upplysningar om mer än 200 samhällen, ordnade på så sätt att tillgängliga uppgifter rörande varje gren av deras kultur lätt kan återfinnas" ${ }^{4}$ ). I boken räknas 189 samfund upp och bland dessa återfinnas under rubriken „Eurasien“ lapparna med jakuter och jukagirer som närmaste grannar. Ordlistan i slutet av boken (s. 357) innehåller följande definition: ,Lappar, ett folk i norra Skandinavien. Har renskötsel. En del, de s.k. kustlapparna

4) Se Frank A. Beach och Clellan S. Ford, Sexualitet hos människor och djur i antropologiskt och biologiskt perspektiv, 1952, s. $23-25$. 
jagar och fiskar. Strikt monogama“河). Vidare sägs (s. 23 n) : „En utvald samling av de källskrifter, som begagnats, återfinnas i slutet av boken“. I litteraturförteckningen (s. 340-344) återfinnas dock icke något arbete om denna folkgrupp. Human Relations Area Files är en vetenskaplig institution i anslutning till Yale University, New Haven, Connecticut, USA. Dess föreståndare är den i not 4 nämnda Clellan S. Ford. Dess grundläggande verksamheten är att samla och sprida organiserade data om olika kulturer. Samlingen baserar sig på både engelsk och annan litteratur inom etnografi, antropologi, sociologi och andra samhällsvetenskaper. F.n. har institutet material om 220 olika folkgruppers kulturer. Om samerna finns 14 källor i samlingen på sammanlagt 3.019 sidor. Dessa finnas även i mikrofilmat skick. En förteckning över dessa källor upptager 13 böcker, därav 12 på engelska, bl. a. av de nordiska författarna Rafael Karsten, Björn Collinder, Gutorm Gjessing och Ernst Mauker, samt en på finska. ${ }^{6}$ ) Institutet har emellertid ej något att göra med att samerna av Palmer betecknas som illitterata utan har endast tillhandahållit grundmaterialet om de 58 olika kulturerna till professor Palmer, och det är sedan han som karakteriserat dem på sådant sätt.

Professor Palmer själv har på förfrågan lämnat ett mycket intetsägande svar, som innebär att han tagit sina data om samerna från redogörelser från tiden före skriftspråkets utveckling där. Detta framgår emellertid varken av själva artikeln eller av den nyssnämnda förteckningen över de i Human Relation Area Files befintliga verken.

Vad gäller frågan, om när samerna i Sverige kunde börja räknas som litterata beror detta givetvis på när skolundervisningen kunde anses allmän. Under 1800-talet fumnos dels de s.k. kateketskolorna, dels Svenska Missionssällskapets skolor, varefter år 1913 en ny och mera allmängiltig skolordning trädde i kraft. ${ }^{7}$ )

Som ett par exempel ur den rika litteratur som motsäger påståendet att samerna äro illitterata kumna nämnas Johan Turi, Muittalus samid birra. En bog om Lappenes Liv (1910), Nils Nilsson Skum, Same sita - lappbyn (1938), Erik Solem, Lappiske rettsstudier (1933), Ernst Manker, De svenska fjälllapparna (1947), Israel Ruong, Samerna (1969) samt Nordiska Museets

5) Man behöver sålunda i detta sammanhang ej räkna med de cirka 1.800 samerna i nordvästra Ryssland (se Svensk Uppslagsbok, 2 uppl. 1965, band 17, spalt 817 ).

$\left.{ }^{6}\right)$ Upplysningar i brev samt tillhörande material från Timothy $J$. O'Leary, Chief Analyst vid institutet.

${ }^{7}$ ) För denna upplysning står jag i tacksamhetsskuld till professor Israel Ruong, Uppsala. Jämför även SOU 1960:41, Samernas skolgång. 
sedan 1938 utkommande publikationsserie "Acta Lapponica“. De första lapska böckerna utkommo i Sverige redan $1619 .^{8}$ )

Klas Lithner.

8) Se uppslagsordet Lapska spráket och litteraturen, Svensk Uppslagsbok, 2 uppl., 1965, band 17, spalt 855 . Beträffande samernas aktuella ställning i Sverige och Norge kan som en politisk kuriositet hänvisas till Sydafrikas livliga intresse i FN för detta problem. Jämför David Schwarz, Svensk invandrings- och minoritetspolitik (1971) s. $48-50$. 